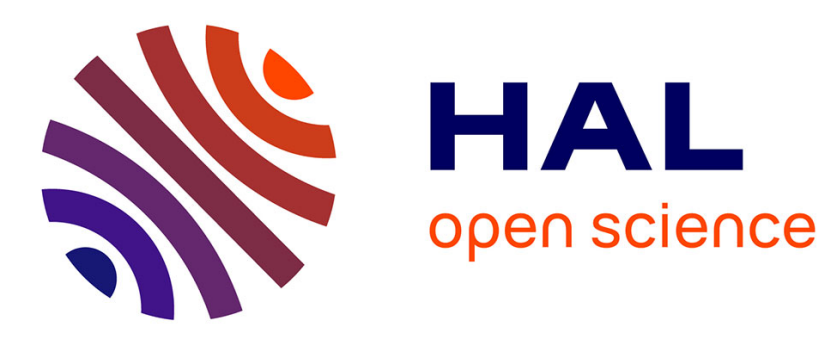

\title{
Business Models and Modelling Business Models
}

Charles Baden-Fuller, Vincent Mangematin

\section{To cite this version:}

Charles Baden-Fuller, Vincent Mangematin. Business Models and Modelling Business Models. Advances in Strategic Management, 2015, Business Models and Modelling, 33, pp. xi - xxii. 10.1108/s0742-332220150000033013 . hal-01183386

\section{HAL Id: hal-01183386 \\ http://hal.grenoble-em.com/hal-01183386}

Submitted on 7 Aug 2015

HAL is a multi-disciplinary open access archive for the deposit and dissemination of scientific research documents, whether they are published or not. The documents may come from teaching and research institutions in France or abroad, or from public or private research centers.
L'archive ouverte pluridisciplinaire HAL, est destinée au dépôt et à la diffusion de documents scientifiques de niveau recherche, publiés ou non, émanant des établissements d'enseignement et de recherche français ou étrangers, des laboratoires publics ou privés. 


\title{
Business Models and Modelling Business Models
}

\author{
Charles Baden-Fuller \\ Cass Business School, City University London \\ Vincent Mangematin \\ Grenoble Ecole de Management (GEM)
}

\section{Introduction}

The business model topic has generated a lot of discussion since the phrase first gained currency in academic articles the late 1990s (Zott, Amit \& Massa, 2011). This growing attention culminated in the 2010 Long Range Planning Special Issue that brought the field's leading scholars together to answer questions about what the business model was and what was its purpose. A key point that emerged was that a business model is more than a statement of how "value is created and captured"; it is a 'model' - and, like many other kinds of models - can appear in many guises and serve many purposes. These include being a 'manipulable device' that can be used to help academics or managers understand the linkages between value creation and value capture more clearly; as well as being an artefact that can be used to convey knowledge about a business and its status to others (see for instance, Morgan and Morrison, 1999; Teece, 2010, Baden-Fuller \& Morgan, 2010). The Special Issue (and subsequent pieces) also re-emphasized the critical question of how changing technology influences business model choice (Chesbrough, 2010; Gambardella \& McGahan, 2010) and the model itself (Baden-Fuller \& Haefliger, 2013; Baden-Fuller \& Mangematin, 2013); and a shift of attention away from matters internal to the firm towards what happens at and beyond its boundaries, and the relationships between the firm and its customers (see, especially, Teece, 2010); and the role of the business model as an expression of the firm's governance arrangements that span not just internally and backwards down the value chain, but all the way through to the customer (Casadesus-Masanell \& Ricart, 2010).

Despite all this work, there are gaps to be filled: which include the exploration of business models as a process as well as an output. By this we mean a proper expression of how business models emerge, and how they can be and are used, and a realization that exploring these issues will shed light on how and where the business model concept can be useful in our work as academics and practitioners; and assist in overcoming the fears and concerns of sceptics who feel that the 'business model' is just another concept that adds too 
little to our understanding of strategy (e.g. Markides, 2015). We use the words 'strategizing', 'modelling' and 'enacting' to emphasize the authors' contributions to the process dimensions of business model work. In particular, we dig into how the strategy agenda is being shaped by this understanding of 'business models as models', and explore what it means to 'model the business model', and some of the consequences of that modelling. In this way, we clarify what the 'business model as a model' lens means for our understanding of strategic management, and make links with other important literatures.

\section{Part I: Strategizing with Business Models}

Our opening section (see Table 1) presents 5 contributions that pay special attention, not just to what business models are, but also to how they emerge, so sharpening our understanding of the value added nature of using 'models' in that framing

Casadesus-Masanell and Heilbron (2015) revisit what is meant by the words 'business model as a model' and how that concept adds value to traditional strategy notions. They emphasize an important overlooked profit opportunity - 'ambivalent value' - making an important linkage between economic thinking and strategy that reveals a dimension ignored by traditional strategy analysis.

Benoît Demil and Xavier Lecoq (2015) look at the processes by which managers construct and reconstruct the business models that frame their decisions about their businesses. Adopting the rigorous Actor Network Theory methodology, they pay attention not only to what managers say, but also to the artefacts that they construct as they build a new business model. This provides an important linkage for strategy scholars seeking to undertake empirical work on strategy process

Tatiana Mikhalkina and Laure Cabantous (2015) take categorization research as a framing to understand and provide a systematic account of how strategy ideas get shaped and how they travel. They do this by asking "How did AirbnB emerge and subsequently become an iconic market-place platform business model and an exemplar of the 'sharing economy', and thus become a benchmark for other firms?" Their analysis provides a valuable basis for others to understand how new business models come into being, and how they are interpreted by the media, and can thus be reinterpreted by other actors who can reuse the ideas in other situations. 
Ryan Rumble and Vincent Mangematin (2015) look at the role of analogical vs. logical thinking in the formation of new business models. They argue that the complexity of the multi-sided-business-model platform business is much greater than the traditional product and work-for-hire business, so that firm formation happens differently. Platform business models are utilized by firms that simultaneously engage with two different customer groups, a user group that receives something for zero payment, and another group that either pays to be allowed to advertise to that first group, or to buy data about it. They use QCA analysis to show how firms choosing to operate multi-sided platforms have different trajectories to those operating single-sided BMs: and that, typically - but perhaps surprisingly - the former eschew rational planning but instead rely heavily on analogical reasoning. The results are strongly suggestive that traditional strategy thinking and toolkits are not up to the task of comprehending and assisting modern businesses - a gap that needs to be filled by academics and practitioners.

Costas Markides (2015) reviewing the interface between strategy and business models, reminds us that that new ideas need to show how they add value - rather than merely repeat and rebadge older, already-established knowledge. In this volume, the contributions recognize this challenge.

Table One: Strategizing with Business Models

\begin{tabular}{|c|c|c|c|c|}
\hline & $\begin{array}{l}\text { Business Model } \\
\text { Definition }\end{array}$ & Focus of attention & Linkages & Key findings \\
\hline $\begin{array}{l}\text { Casadesus- } \\
\text { Masanell \& } \\
\text { Heilbron }\end{array}$ & $\begin{array}{l}\text { A model of the } \\
\text { decisions of the } \\
\text { firm }\end{array}$ & $\begin{array}{l}\text { The boundaries of the firm } \\
\text { and "ambient value" }\end{array}$ & Economics & $\begin{array}{l}\text { Business model } \\
\text { perspective unlocks } \\
\text { hidden value at the } \\
\text { firm's boundary }\end{array}$ \\
\hline $\begin{array}{l}\text { Demil \& } \\
\text { Lecoq }\end{array}$ & $\begin{array}{l}\text { A cognitive model } \\
\text { requiring artifacts } \\
\text { to become an } \\
\text { organizational } \\
\text { reality }\end{array}$ & $\begin{array}{l}\text { The decisions of managers } \\
\text { and the artefacts created }\end{array}$ & $\begin{array}{l}\text { Socio-materiality } \\
\text { \& ethnography }\end{array}$ & $\begin{array}{l}\text { How managers can } \\
\text { change their } \\
\text { business model }\end{array}$ \\
\hline $\begin{array}{l}\text { Mikhalkina \& } \\
\text { Cabantous }\end{array}$ & $\begin{array}{l}\text { A prototype - story } \\
\text { that provides } \\
\text { inspiration for } \\
\text { others to copy }\end{array}$ & $\begin{array}{l}\text { How a firm can develop its } \\
\text { story to become an iconic } \\
\text { exemplar business model } \\
\text { for others }\end{array}$ & $\begin{array}{l}\text { Social category } \\
\text { theory }\end{array}$ & $\begin{array}{l}\text { Role of audience } \\
\text { engagement in } \\
\text { business model } \\
\text { emergence }\end{array}$ \\
\hline $\begin{array}{l}\text { Rumble \& } \\
\text { Mangematin }\end{array}$ & $\begin{array}{l}\text { A model of which } \\
\text { there are ideal types }\end{array}$ & $\begin{array}{l}\text { Where do entrepreneurs } \\
\text { obtain their ideas? }\end{array}$ & $\begin{array}{l}\text { Antecedents of } \\
\text { business ideas, } \\
\text { QCA analysis }\end{array}$ & $\begin{array}{l}\text { Platform business } \\
\text { models (in France) } \\
\text { are created by } \\
\text { analogy rather than } \\
\text { logic }\end{array}$ \\
\hline Markides & & $\begin{array}{l}\text { Traditional strategy } \\
\text { analysis - and the } \\
\text { challenge faced by } \\
\text { business model scholars }\end{array}$ & $\begin{array}{l}\text { Traditional } \\
\text { strategy }\end{array}$ & \\
\hline
\end{tabular}


Business Models and Modelling Business Models

\section{Part 2: Modelling the Business Model}

In our second section, we present four contributions that focus on the modelling process - that is, what it means for business models to be designed and manipulated (summarized in Table 2).

Paolo Aversa, Stefan Haefliger, Alessandro Rossi and Charles Baden-Fuller (2015) address the critical question of how best to model the business model. Drawing on the work of Simon (1962) on how systems can be nearly decomposable, and paying attention to the literature on modularity, they explore the necessary conditions for effective manipulation of a business model - something that requires the user to 'black-box' or 'hide' parts of the system to avoid confusion. They draw parallels between this approach and the modularity of technology debates; and they borrow from Baldwin and Clark's (2000) manipulation mechanisms to explore what it means to manipulate business models. The article contributes to our appreciation that it is not just a question of thinking with models, but also specifying what their focus is - a matter argued persuasively by Morgan (2012) in the context of economic models and modelling.

Moritz Loock and Fredrik Hacklin (2015), delve into the logic behind business model framing, exploring what exactly is the model of a business model. They argue that the foundations of business models should be seen as heuristics (e.g. Gigerenzer, Hertwig \& Pachur, 2011) that model individual cognition. By drawing on gestalt theory to specify the principles of modelling as rule-based form-giving, they unpack the meaning and logic behind the proper use of business models. Their paper provides a strong micro-foundation for the use of business models and modelling with business models in cognitive research (and action) in the field of strategy.

Santi Furnari (2015) examines another aspect of the challenge of modelling with business models - the causal basis of reasoning. He argues that cognitive maps are a useful mechanism for visualizing the cause-and-effect relationships that underpin business model thinking in the minds of managers (or academics). These maps shed light on four important dimensions of their causal structure: complexity, focus, clustering and characterization.

Joanne Jin Zhang, Yossi Lichenstein and Jonathan Gander (2015) take the classical strategy question about scale and success identified by Chandler (1990), and explore it in the context of digital businesses. They identify four important issues that determine successful 
scaling: engaging both paying and non-paying user-customers through learning by using and through network externalities; leveraging these by exploiting informational increasing returns in production and distribution; exploiting technological relatedness; and distributing resources effectively. Whilst none of these factors is individually unknown, analyzing them together shows how, where and when they relate and cumulate.

\section{Table Two: Modelling the Business Model}

\begin{tabular}{|l|l|l|l|}
\hline & Focus of attention & Key literatures & Claim \\
\hline $\begin{array}{l}\text { Aversa, } \\
\text { \& Baden-Fuller }\end{array}$ & $\begin{array}{l}\text { Business model design and } \\
\text { manipulation - and its } \\
\text { relation to technology }\end{array}$ & $\begin{array}{l}\text { Decomposability and } \\
\text { manipulation of model; } \\
\text { Technology, } \\
\text { decomposability and } \\
\text { modularity }\end{array}$ & $\begin{array}{l}\text { That effective manipulation } \\
\text { requires a focus of attention } \\
\text { - and that there is an } \\
\text { important difference when } \\
\text { that is internal to the firm } \\
\text { from when it focuses on the } \\
\text { boundary }\end{array}$ \\
\hline $\begin{array}{l}\text { Loock \& } \\
\text { Hacklin }\end{array}$ & $\begin{array}{l}\text { Business models as a } \\
\text { cognitive tool for modelling }\end{array}$ & $\begin{array}{l}\text { Heuristics; } \\
\text { Gestalt theory }\end{array}$ & $\begin{array}{l}\text { Business Models are } \\
\text { founded on heuristics and } \\
\text { rely on gestalt theory for } \\
\text { their legitimacy }\end{array}$ \\
\hline Furnari & $\begin{array}{l}\text { Causal structure of business } \\
\text { cognitive representation of } \\
\text { business value creation and } \\
\text { capture }\end{array}$ & $\begin{array}{l}\text { Cognition and modelling } \\
\text { mental maps }\end{array}$ & $\begin{array}{l}\text { Cognitive maps can be a } \\
\text { powerful method to unpack } \\
\text { the nature of cause and } \\
\text { effect; especially } \\
\text { complexity, focus and } \\
\text { clustering }\end{array}$ \\
\hline $\begin{array}{l}\text { Zhang, } \\
\text { Lichenstein, \& }\end{array}$ & $\begin{array}{l}\text { Howder } \\
\text { model permit young } \\
\text { businesses to scale more } \\
\text { effectively }\end{array}$ & $\begin{array}{l}\text { Scaling in Economics and } \\
\text { Strategy }\end{array}$ & $\begin{array}{l}\text { Role of customer learning, } \\
\text { customer networks and } \\
\text { technology in scaling of } \\
\text { digital businesses }\end{array}$ \\
\hline
\end{tabular}

\section{Part 3: Enacting Business Models}

Our last four contributions examine how businesses enact business models and business model thinking (see Table 3). S. Ramakrishna Velamuri, Priya Anant and Vasantha Kumar (2015) examine the extraordinary successes of three Indian healthcare organizations that have scaled successfully - and provided care for enormous numbers of poor patients at the same time. Their business models combine Fordist principles of quality and scale, and more modern notions of business model thinking that stress the need for customer selection and customer engagement. They do not rely on traditional notions of charity - money being collected from individuals or governments to subsidize the poor - nor on the notion that low cost means low quality: but rather show how an effective 'for profit' business model can be socially oriented, resulting in considerable direct outcomes for low income groups in need of quality healthcare - and even more potent indirect ones for national healthcare models. This is quite a departure from traditional thinking and conventional practice. 
Deirdre McQuillan and Pamela Sharkey Scott (2015) explore how professional service firms internationalize, and show how the business model lens can increase the power of traditional explanations. Most IB theories look at the firm as the unit of analysis: these authors show that shifting attention to internationalizing events adds explicatory power otherwise missed. They show how a business model perspective on such events focuses on the client and the firm/client interfaces, and how such service firms run portfolios of contrasting dominant and secondary business models.

Florian Waldner, Marion K. Poetz, Christoph Grimpe and Markus Eurich (2015) look at the interface between the firm and its industry environment, claiming that industry factors moderate the firm's propensity to innovate and its choice of business model. They contribute by providing one of the first really large sample works on business model innovation, examining how industry life-cycle stages and sector competitiveness affect the likelihood of Austrian firms innovating their business models, and the effects of such innovation on firm performance.

Finally, we end with a piece by Koen van den Oever and Xavier Martin (2015) that looks carefully at the critical role middle managers play in how business models are chosen and enacted. Drawing on the framing literature of change management, they show how middle managers in Dutch water authorities leveraged their understanding of micro and macro situations to drive change, using issue selling and championing techniques to guide senior managers and their boards towards approving plans for radical business model change. 
Table 3: Enacting Business Models

\begin{tabular}{|c|c|c|c|c|}
\hline & $\begin{array}{l}\text { Novel dimension of } \\
\text { enactment }\end{array}$ & Drivers of enactment & Data & $\begin{array}{l}\text { Contribution to } \\
\text { theory }\end{array}$ \\
\hline $\begin{array}{l}\text { Velamuri, } \\
\text { Anant \& Kumar }\end{array}$ & $\begin{array}{l}\text { What are the } \\
\text { dimensions of } \\
\text { effective } \\
\text { economically } \\
\text { sustainable but } \\
\text { social business } \\
\text { models in Health } \\
\text { Care? }\end{array}$ & $\begin{array}{l}\text { Key to effectiveness is } \\
\text { having a single business } \\
\text { model built on Fordist } \\
\text { principles of scale and } \\
\text { efficiency, without } \\
\text { compromising quality. } \\
\text { Customer engagement is } \\
\text { key to success }\end{array}$ & $\begin{array}{l}3 \text { private health } \\
\text { care hospitals that } \\
\text { successfully } \\
\text { scaled }\end{array}$ & $\begin{array}{l}\text { Social business } \\
\text { models need not } \\
\text { be (very) } \\
\text { different from } \\
\text { profit business } \\
\text { models }\end{array}$ \\
\hline $\begin{array}{l}\text { McQuillan \& } \\
\text { Sharkey Scott }\end{array}$ & $\begin{array}{l}\text { How do professional } \\
\text { service firms choose } \\
\text { their business model } \\
\text { to effectively } \\
\text { globalize? }\end{array}$ & $\begin{array}{l}\text { Choice of the business } \\
\text { model takes place at the } \\
\text { level of the project - not the } \\
\text { firm. Coherence matters, } \\
\text { but uniformity is not } \\
\text { essential for success. } \\
\text { Middle managers play a key } \\
\text { role. }\end{array}$ & $\begin{array}{l}10 \text { firms that } \\
\text { internationalized } \\
\text { successfully but } \\
\text { in different ways }\end{array}$ & $\begin{array}{l}\text { Theories of } \\
\text { internationalizat } \\
\text { ion should have } \\
\text { the business } \\
\text { model as unit of } \\
\text { analysis }\end{array}$ \\
\hline $\begin{array}{l}\text { Waldner, Poetz, } \\
\text { Grimpe \& } \\
\text { Eurich }\end{array}$ & $\begin{array}{l}\text { How does (and } \\
\text { should) the firm } \\
\text { innovate its business } \\
\text { model over the life } \\
\text { cycle of an industry? }\end{array}$ & $\begin{array}{l}\text { Firms (inside the industry) } \\
\text { innovate more at the start of } \\
\text { the industry life-cycle, and } \\
\text { less when competition is } \\
\text { intense. }\end{array}$ & $\begin{array}{l}\text { Cross section } \\
\text { sample of } 1,242 \\
\text { Austrian firms } \\
\text { and business } \\
\text { model choices }\end{array}$ & $\begin{array}{l}\text { Industry factors } \\
\text { as a moderator } \\
\text { of business } \\
\text { model choice }\end{array}$ \\
\hline $\begin{array}{l}\text { Van den Oever } \\
\text { \& Martin }\end{array}$ & $\begin{array}{l}\text { How do (and should) } \\
\text { middle managers } \\
\text { identify and } \\
\text { champion business } \\
\text { model change in } \\
\text { large firms }\end{array}$ & $\begin{array}{l}\text { Middle managers play a key } \\
\text { role in championing } \\
\text { business model innovation, } \\
\text { particularly when outside } \\
\text { stakeholders are pressing } \\
\text { for change. They can } \\
\text { combine the external } \\
\text { pressures with their own } \\
\text { concerns to effect }\end{array}$ & $\begin{array}{l}\text { Significant } \\
\text { change in } \\
\text { business models } \\
\text { taking place in } \\
\text { Dutch water } \\
\text { authorities } \\
\text { charged with } \\
\text { dams and other } \\
\text { land protection }\end{array}$ & $\begin{array}{l}\text { Framing theory } \\
\text { and the role of } \\
\text { middle } \\
\text { managers in } \\
\text { bridging } \\
\text { stakeholders to } \\
\text { achieve business } \\
\text { model change }\end{array}$ \\
\hline
\end{tabular}

\section{Discussion}

So what next? By taking a process perspective, our essays mobilize strategizing, modelling and enacting perspectives to bring the business model agenda closer to the core considerations of strategic management. But our essays also signal some further gaps.

The first challenge is to discern the extent to which the triadic business models of market-places such as Uber or the multi-sided platforms such as Google require a different set of managerial capabilities and capacities in both thinking and doing Three of our essays suggest that firms that adopt these business models face unusual challenges, whether it is in the antecedents of their thinking (Rumble and Mangematin), in how they are designed and manipulated (Aversa, Haefliger, Rossi and Baden-Fuller) or in how they become iconic (Mikhalkina and Cabantous). Firms adopting these business models have to be creative in how they use technology, as successful platform business models appear to use digital technologies both in delivering the content (which can be wholly digital as with Google, or 
can contain strong elements of creativity, as in video games) and also in using technology to alter the dynamics of the pricing and engagement aspects of the business (the charging mechanisms of most multi-sided platforms depend on computer based algorithms, and the linking mechanisms of the sharing economy also have algorithmic aspects). This view has strong support from leading economists such as Rochet and Tirole (2005) who explain that multi-sided business models obey different economic pricing laws to those that govern traditional product firms.

The second challenge is to consider what business model innovation means for strategists (both academics and practitioners). The traditional heartland concerns are shifting away from being about how technology changes the cost side of the firm (providing better production, better delivery, new ways of configuring assets, and new ways of outsourcing work) towards novel ways of engaging customers and getting them to pay. This is where the concept 'business model as a model' becomes vitally important, because the business model concept asks: "Who is the customer?", "What is the value created for that customer in his or her interaction with the firm?" and "How is that value to be monetized (directly or indirectly)?”- see Teece, 2010, Baden-Fuller \& Mangematin, 2013; Baden-Fuller \& Haefliger, 2013. This highlights new dimensions that encompass not just triadic business models, but also features such as the sharing economy that are hard to grapple with using traditional strategy tools. These business models require academics and managers to recognize how the same product can be delivered to customers in quite different ways, with quite different effects. So competition between firms has become not just a question of competition based on better product offerings, but also on more effective business models. Inferior quality offers at zero price from multi-sided platform business models (YouTube or advertising supported video games), and offers from sharing economy business models with different cost structures are (for some audiences) highly competitive with higher quality offers from more traditional players using traditional product business models. Put another way, a product based business model firm that asks 'Who is the customer?' is faced with the possible answer that there may not be just one customer but several - because a competing firm operating a multi-sided platform or sharing economy business model will interest other customer groups, and are altering the dynamics of whole industries. For academics, this is challenging. The firms under study many not have changed their business model at all; but if others have done so, then the industry and its eco-system have changed - and traditional analytical tools that measure the value of an asset, how competition takes place and how competitive advantage is created and distributed will have to be reconsidered and 
recalibrated.

This leads to the important corporate strategy agenda that has been almost completely overlooked. Business models do not map on to firms in a one to one manner. Many firms run portfolios of business models: in the case of large diversified firms it is typically the consequence of diversification moves that involve exploiting competencies in different ways across multiple customer groups. This results in different divisions capitalizing on common capabilities to sell products one way in one market, and in a different way in another market. For small firms, such portfolios are often created out of necessity: there may not be sufficient demand for their preferred product for the entrepreneur to survive, so he or she will sell consultancy time to monetize their slack capacity. We know almost nothing of the merits of running these portfolios, and whether firms that have replicated business models across time and space (as is common in the fast food industry with McDonald's being an exemplar) are more successful than those that seek to adjust to specific circumstances in each instance, risking creating coordination challenges. How replication, modification and adaptation influence firm success in running portfolios becomes an important research question, that has been highlighted by writers such as Winter and Szulanski (2001).

\section{Acknowledgements}

We gratefully acknowledge the support of Brian Silverman, Senior Editor for allowing us to undertake this project and supporting us at every stage, and we thank all the participants at the Business Model Mini Conference at Cass Business School for their precious suggestions. We thank Jon Morgan of Paraphrase, who has copy-edited all the papers in this volume. This work was supported by the EPSRC UK Research Council (EP/K039695/1 Building Better Business Models). 


\section{References}

Aversa P., Haefliger S., Rossi A \& Baden-Fuller C. (2015). From Business Model to Business Modeling: Modularity and Manipulation, Advances in Strategic Management, forthcoming.

Baden-Fuller C. \& Morgan M.S. (2010). Business models as models. Long Range Planning, 43(2-3): 156-171.

Baden-Fuller C. \& Haefliger S. (2013). Business Models and Technological Innovation. Long Range Planning, 46(6): 419-426.

Baden-Fuller C. \& Mangematin V. (2013). Business models: A challenging agenda. Strategic Organization, 11(4): 418-427.

Baldwin C.Y. \& Clark K.B. (2000). Design rules: The power of modularity: The MIT Press.

Casadesus-Masanell R. \& Ricart J.E. (2010). From strategy to business models and onto tactics. Long Range Planning, 43(2-3): 195-215.

Casadesus-Masanell R. \& Heilbron J. (2015). The Business Model: Nature and Benefits, Advances in Strategic Management, forthcoming.

Chandler A. (1990). Scale and scope: the dynamics of industrial capitalism, Harvard University Press.

Chesbrough H. (2010). Business model innovation: opportunities and barriers. Long Range Planning, 43(2-3): 354-363.

Demil B. \& Lecocq X. (2015). Crafting an innovative business model in an established company: The role of artifacts, Advances in Strategic Management, forthcoming.

Gambardella A. \& McGahan A.M. (2010). Business-model innovation: General purpose technologies and their implications for industry structure. Long Range Planning, 43(2-3): 262-271.

Furnari S. (2105). A Cognitive Mapping Approach to Business Models: Representing Causal Structures and Mechanisms, Advances in Strategic Management, forthcoming.

Gigerenzer G., Hertwig R. \& Pachur T. (2011). Heuristics: The foundations of adaptive behavior. New York: Oxford.

Loock M. \& Hacklin F. (2015). Business Modeling as Configuring Heuristics, Advances in Strategic Management, forthcoming.

Markides C.C. (2105). Research on Business Models: Challenges and Opportunities, Advances in Strategic Management, forthcoming.

McQuillan D. \& Sharkey Scott P. (2015). Models of Internationalization: a business model approach to professional service firm internationalization, Advances in Strategic Management, forthcoming.

Mikhalkina T. \& Cabantous L. (2015). Business Model Innovation: How Iconic Business Models Emerge, Advances in Strategic Management, forthcoming.

Morgan M.S. (2012). The world in the model: how economists work and think: Cambridge University Press.

Morgan M.S. and Morrison M.C. (1999) Models as Mediating Instruments in Models as Mediators (ed M.S. Morgan and M.C. Morrison):10-37, Cambridge University Press, Ideas in Context Series.

Rochet J.C. \& Tirole J.( 2003). Platform competition in two-sided markets. Journal of the European Economic Association, 1(4): 990-1029.

Rumble R. \& Mangematin V. (2015). Business Model Implementation: The Antecedents of MultiSidedness, Advances in Strategic Management, forthcoming.

Simon H.A. (1962). The Architecture of Complexity. Proceedings of the American Philosophical Society, 106(6): 467-482.

Teece D.J. (2010). Business models, business strategy and innovation. Long Range Planning, 43(2-3): 172-194.

van den Oever K. \& Martin X. (2015). Business model change: Managerial roles and tactics in 
decision-making, Advances in Strategic Management, forthcoming.

Velamuri S.R., Anant P. \& Kumar V. (2015). Doing Well to do Good: Business Model Innovation for Social Healthcare, Advances in Strategic Management, forthcoming.

Waldner F., Poetz M.K., Grimpe C. \& Eurich M. (2105). Antecedents and consequences of business model innovation: The role of industry structure, Advances in Strategic Management, forthcoming.

Winter, S.G. \& Szulanski G. 2001. Replication as strategy. Organization Science 12(6) 730-743.

Zhang J.J., Lichtenstein Y. \& Gander J. (2015). Designing Scalable Digital Business Models, Advances in Strategic Management, forthcoming.

Zott C., Amit R. \& Massa L. (2011). The business model: recent developments and future research. Journal of Management, 37(4): 1019-1042.

\section{Biographies}

Charles Baden-Fuller is the Centenary Professor of Strategy at Cass Business School, City

University London and is a Senior Fellow at the Wharton School, University of Pennsylvania. He has contributed to many lines of thinking in the Strategy field, including cognition, organizational change, networks and alliances, and in many contexts including mature industries and biotechnology.

Recently he has been associated with thinking concerning business models through his promotion of the concept of 'Business Models as models' and his role as leading editor of the 2010 Long Range Planning Special Issue on Business Models. Cass Business School, City University London 106 Bunhill Row, London, EC1Y 8TZ UK.e-mail: c.baden-fuller@city.ac.uk

Vincent Mangematin is a professor and scientific director at Grenoble Ecole de Management. He researches the transformative influence of digital technologies, focusing on business models as an approach to renew strategy. He is associate editor of Technovation and M@n@gement and serves on the editorial boards of Organization Studies, Research Policy and Long Range Planning. Grenoble Ecole de Management 12, rue Pierre Sémard, 38000, Grenoble, France.e-mail: vincent.mangematin@grenoble-em.com works: http://scholar.google.fr/citations? user=sM8-loEAAAAJ\&hl=fr. 